UDC005.53:628.1

Survey Paper

\title{
Using AHP Method for Making a Decision on How the Management of Sewage Sludge in the Northern Croatia
}

Vesna Dušak

Faculty of Organization and Informatics

University of Zagreb, Varazdin, Croatia

Lovorka Gotal Dmitrović

University centre Varazdin

University North, Varazdin, Croatia

Renata Bagnall

Faculty of Social Science

The Open University, Milton Keynes, United Kingdom vesna.dusak@foi.hr

lgotaldmitrovic@unin.hr

re.bagnall@yahoo.com

\begin{abstract}
By 2018, in Croatia, the agglomerations for collecting the sewage and water treatment systems are going to be constructed. All devices will be based on the mechanicalbiological method of purification. However, the work of water treatment system produces a problem of sludge management.

The paper presents the challenges of wastewater sludge handling and makes a decision on further sludge management. The hierarchical model of the decision making problem by defining the goal, criteria and alternative solutions is developed. On each level of the hierarchical model the elements of the model are compared with each other in pairs, and the preferences are expressed by using the Saaty's scale.

Moreover, the APH model compares the alternative pairs (thermal processing, deposition on agricultural land, disposal to waste repositories and composting) among each others. The intensities and weight preferences of one alternative over another are selected within the required criteria (economic, environmental, organisational and sociological).
\end{abstract}

Keywords: sewage sludge, AHP method, disposal processes

\section{Introduction}

Northern Croatia is the name for the area of the Croatia northernmost part. It is not an official term, but is often used as a descriptive geographical definition. Northern Croatia includes four counties: Medjimurska, Varazdinska, Koprivnicko-krizevacka and Krapinsko-zagorska. This area stretches the state border with Slovenia and Hungary. In terms of demography that is a relatively densely populated area, where in some places the population density exceeds 150 inhabitants per square kilometre, which is twice the national average. 
According to the Council Directive 91/271/EEC concerning urban waste-water treatment ${ }^{1}[12]$ by the end of 2018, the systems for collection and treatment of urban waste water in the first group of agglomerations of more than 15,000 population equivalent (PE) should build. At the end of 2023 all obligations for remaining agglomerations will be completed.

Agglomerations larger than $2000 \mathrm{PE}$ in [6]:

- Medjimurska County are (alphabetical order): Belica, Cakovec, Donja Dubrava, Donji Kraljevec, Drzimurec, Gorican, Kotoriba, Mursko Sredisce, Novo Selo na Dravi, Podbrest, Podturen, Sveti Martin na Muri, Turcisce;

- Varazdinska County are (alphabetical order): Cestica, Greda, Ivanec, Jalzabet, Lepoglava, Ludberg, Novi Marof, Semovec, Varazdin, Varazdinske Toplice and Veliki Bukovec;

- Koprivnicko-Krizevacka County are (alphabetical order): Bjelovar, Cazma, Daruvar, Djurdjevac, Garesnica, Grubisno Polje, Gudovac, Hercegovac, Koprivnica, Krizevci, Novigrad Podravski, Podravske Sesvete, Rovisce, Virje;

- Krapinsko-Zagorska County are (alphabetical order): Bedekovcina, Hum na Sutli, Jakovlje, Konjscina, Krapina, Krapinske Toplice, Marija Bistrica, Pregrada, Zabok, Zlatar, Zapresic.

According to the population equivalent (PE), Medjimurska County is $147.608 \mathrm{PE}$, Varazdinska County 187.033 PE, Koprivnicko-Krizevacka County 219.735 PE and Krapinsko-Zagorska County 164.616 PE, total: 718.992 PE. The population equivalent will produce approximately $75.000 .000 \mathrm{~m}^{3} / \mathrm{y}$ of waste waters. Purification of these waste waters will occur, approximately $45.000 \mathrm{t} / \mathrm{y}$ of stabilised and dried waste sludge.

\section{AHP method}

Psychological research shows that the human brain works one-dimensional. At the level of comparing two objects, there was a problem to give a definite but subjective greater score of objects [7]. An additional problem arises with decision-making by introducing criteria depending on priorities that differently influence the decisions. These problems deal with multi-criteria decision-making methods. The multi-criteria method includes hierarchical methods. A hierarchical method used in this paper is Saaty's method eigenvector or Analytic Hierarchy Process (AHP) [8].

The Analytic Hierarchy Process is a structured technique for organising and analysing complex decisions. It was developed by Thomas L. Saaty in the 1970s and has been extensively studied and refined since then. It has particular application in group decision making, and is used in a wide variety of decision situations [9].

\footnotetext{
${ }^{1}$ The Directive refers to all agglomerations of more than 2,000 population equivalent, agglomerations of less than 2,000 PE that have built sewage system, food industry load over 4,000 PE and discharging treated wastewater directly into the receiver.
} 
First, it decomposes the problems into a hierarchy of more easily comprehended sub-problems, each of which can be analysed independently. The elements of the hierarchy can relate to any aspect of the decision problem - tangible or intangible, carefully measured or roughly estimated, well or poorly understood - anything should be applied to the hierarchy.

Once the hierarchy is built, the decision makers systematically evaluate its various elements by comparing them to each other two at a time, with respect to their impact on an element above them in the hierarchy. In making the comparisons, the decision makers can use concrete data about the elements, but they typically use their judgements about the elements' relative meaning and importance. It is the essence of the AHP that human judgements, and not just the underlying information, can be used in performing the evaluations. The AHP converts these evaluations to numerical values that can be processed and compared over the entire range of the problem. A numerical weight or priority is derived from each element of the hierarchy, allowing diverse and often incommensurable elements to be compared to one another in a rational and consistent way. This capability distinguishes the AHP from other decision making techniques [8].

In the final step of the process, numerical priorities are calculated for each of the decision alternatives. These numbers represent the alternatives' relative ability to achieve the decision goal, so they allow a straightforward consideration of the various courses of action.

The entire process of the AHP method can be described in several steps:

- The development of the hierarchical model includes the decision-making problem and to define the goal, criteria and alternative solutions.

- On each level of the hierarchical model elements of the model are compared with one another in pairs, and the preferences of the decision maker are expressed with the use of the Saaty's scale (Table 1).

\begin{tabular}{|c|c|l|}
\hline $\begin{array}{c}\text { Intensity of } \\
\text { Importance }\end{array}$ & Definition & \multicolumn{1}{c|}{ Explanation } \\
\hline 1 & Equal importance & Two activities contribute equally to the objective \\
\hline 3 & $\begin{array}{c}\text { Moderate } \\
\text { importance }\end{array}$ & $\begin{array}{l}\text { Experience and judgment slightly favours one } \\
\text { activity over another }\end{array}$ \\
\hline 5 & Strong importance & $\begin{array}{l}\text { Experience and judgment strongly favours one } \\
\text { activity over another }\end{array}$ \\
\hline 7 & $\begin{array}{c}\text { Very strong or } \\
\text { demonstrated } \\
\text { importance }\end{array}$ & $\begin{array}{l}\text { An activity is favoured very strongly over another; } \\
\text { its dominance demonstrated in practice }\end{array}$ \\
\hline $2,4,6,8$ & Extreme importance & $\begin{array}{l}\text { The evidence favouring one activity over another } \\
\text { is of the highest possible order of affirmation }\end{array}$ \\
\hline
\end{tabular}

Table 1 Scale of relative importance for pairwise comparison [10]

In scientific literature that scale is more precisely described as a scale of five levels and four intermediate levels of verbally described intensities and corresponding numerical values for them on the scale from 1 to 9 . The following table shows the 
values and their description used for the comparison of relevant values of the elements of the AHP model [10].

\section{Application of AHP methods}

The idea of AHP method is to set a goal (the disposal of sewage sludge), then set the criteria and influence to meet decisions. Criteria can be classified into one or more levels (first, second...) - this is done by the hierarchy criteria.

The criteria of the first level the most influence on the decision - the most important, while the criteria for the second, third, etc., levels have less impact on the decision. When disposing of sewage sludge criteria of the first level are economic criteria, ecological criteria, social criteria and organisational criteria. Alternatives that are in accordance with the legal framework are:

1. Storage of treated sludge in landfills, either on specific areas or solid waste landfills - non-compliant to the Landfill Directive [11] and obligations transferred to Croatian regulations, such a solution, although it is currently applied in Croatia, is no longer a viable option;

2. Composting with an organic fraction of municipal solid waste and livestock waste - such a solution is viable if there is a large market for biomass. Composting is aerobic process caused by microorganisms and involves mixing and adding additional sources of carbon. In the presence of oxygen, bacteria convert organic material through biological degradation to a stable end product. During decomposition of organic material, compost reaches pasteurisation range temperature $\left(50-70^{\circ} \mathrm{C}\right)$ when enteric pathogenic organisms are destroyed. Composting can reduce the mixture volume by $40-50 \%$. The final product can be used as a soil amendment or fertiliser. Composting, when followed by land application, is considered as one of the most economical ways for the treatment and final disposal of sewage sludge because it combines material recycling with sludge disposal at the same time [1], but despite that final use depends on heavy metal and nutrient concentrations.

3. Use in Agriculture and Forestry - as long as there is enough available land this is a viable option and is practised in many EU member states. Utilisation of sewage sludge for agricultural use is the best alternative for sewage sludge disposal because it recycles both, nutrients and organic matter. Because of the physical-chemical processes that are involved in activated wastewater sludge treatment, sludge tends to accumulate existing heavy metals from the wastewater. Heavy metals such as zinc $(\mathrm{Zn})$, copper $(\mathrm{Cu})$, nickel $(\mathrm{Ni})$, cadmium $(\mathrm{Cd})$, lead $(\mathrm{Pb})$, mercury $(\mathrm{Hg})$ and chromium $(\mathrm{Cr})$ are principal elements restricting the use of sludge for agricultural purposes [4]. Using sludge as fertiliser can represent a potential threat to the environment because of the possible high heavy metal content, a problem that can be aggravated if the toxic metals are mobilised in soil to be taken up by plants or transported in drainage water. The release of heavy metals associated with sewage sludge is strongly influenced by soil $\mathrm{pH}$, causes exchange capacity, organic matter, mobility and speciation of specific metals. Excessive application of sewage sludge to soil has been found to increase the bioavailability of heavy metals, but the low doses of sewage sludge did not cause a significant increase in heavy metal concentrations [4]. Research showed that the 
mineral residue from a limestone quarry amended with sewage sludge can be used for restoration of degraded soils. Although, a high concentration of nitrates and ammonium in leachate was found, which imply an important environmental risk, but important displacements of $\mathrm{Cd}$ and $\mathrm{Ni}$ were found. Therefore, application of sewage sludge and re-vegetation of the land should be carried out before seasonal rainfall period due to the reduction of the risk of excessive loss of $\mathrm{NO}_{3}$ [4]. Due to law restrictions, it is forbidden to dispose of sewage sludge in protected areas such as water protection areas, regional parks, as well as flood areas. After removing the construction area there remains only very small agricultural areas for the disposal of municipal sludge.

4. Thermal treatment - includes energy recovery where the rest (ashes) is used in the construction industry or is landfilled. Since 1998 onwards, European legislation limits possibilities of sewage sludge management. Sea disposal is prohibited, landfilling of sludge is limited due to the high content of biodegradable matter, and agricultural application of sludge is limited due to the high level of heavy metals in sludge. Therefore, the latest trends in the field of sludge management are thermal processes. Incineration is one of the most attractive disposal methods currently in Europe. The calorific value of sewage sludge is similar to brown coal. Incineration leads to large reduction of sludge volume (10\% after mechanical dewatering), thermal destruction of toxic organic compounds minimises odour generation and incineration is followed by energy production. Despite these advantages, ash remaining after incineration usually is considered highly toxic because of its heavy metal content. Public concern about possible harmful emissions from incineration plants, and high costs for process installation and operation are limitation factors for use of this method. Power generation is a major user of fossil fuels and the demand for electricity is growing steadily in the developed world and also in less developed countries. The replacement of all or part of these fossil fuels by renewable energy sources (combustion or co-combustion), such as biomass and waste, is an attractive way of reducing greenhouse gas emission this is possibly the best (cheapest and lowest risk) renewable energy option for many power producers. Untreated sludge mixed with a quantity of compressed air can be treated at higher temperature and pressure. Reaction inside the reactor is exothermal. Gases, liquids and ash leave the reactor. This process is called wet air oxidation. Although there are many advantages (small space requirement, high removal of suspended solids, little odour and air emission, low energy requirements) this process is not yet established for operation and maintenance [4].

Neither alternative is meeting its characteristics neither could be declared to be the best choice. Graphic of the problem is shown in Figure 1.

\begin{tabular}{|c|c|c|c|}
\hline \multicolumn{5}{|c|}{ DISPOSAL OF WASTE SLUDGE } \\
\hline $\begin{array}{c}\text { ENVIRONMENTAL } \\
\text { CRITERIA }\end{array}$ & $\begin{array}{c}\text { ECONOMIC } \\
\text { CRITERIA }\end{array}$ & $\begin{array}{c}\text { SOCIOLOGICAL } \\
\text { CRITERIA }\end{array}$ & $\begin{array}{c}\text { ORGANISATIONAL } \\
\text { CRITERIA }\end{array}$ \\
\hline DISPOSAL & COMPOSTING & AGRICULTURE & THERMAL TREAT.
\end{tabular}

Figure 1 Objective, criteria and alternatives 
The next step is to assess the relative importance of each level criterion. According to Table 1 are assigned to a particular customer object in relation to another object, according to the expression for the weight ratio (1). The weight ratios are defined by following of mathematical relations:

$$
w_{i, j}=\frac{w_{i}}{w_{j}}
$$

where are: $\mathrm{w}_{\mathrm{i}}, \mathrm{w}_{\mathrm{j}}$ - the relative importance of the criteria.

The weight ratios are written in a matrix form of ratios by weight:

$$
\mathrm{w}=\left[\mathrm{w}_{\mathrm{i}, \mathrm{j}}\right]_{\mathrm{qxq}}
$$

where is q a number of criteria. According to the expression (2):

$$
w=\begin{array}{ccc}
w_{11} & \ldots & w_{1 q} \\
\vdots & \ddots & \vdots \\
w_{q 1} & \ldots & w_{q q}
\end{array}
$$

The scores are the mean values of the group ( 5 people) (Table 2 ). Table 2 shows the interdependence of the importance of rating criteria.

\begin{tabular}{|c|c|c|c|c|r|r|}
\hline & $\begin{array}{c}\text { ENVIR. } \\
\text { CRIT. }\end{array}$ & $\begin{array}{c}\text { ECON. } \\
\text { CRIT. }\end{array}$ & $\begin{array}{c}\text { SOCIOL. } \\
\text { CRIT. }\end{array}$ & $\begin{array}{c}\text { ORGANIS. } \\
\text { CRIT. }\end{array}$ & $\begin{array}{c}\text { GEOMETRIC } \\
\text { MEAN }\end{array}$ & PRIORITY \\
\hline ENVIR. CRIT. & 1 & 0,2 & 3 & 5 & 1,316074 & 0,260504 \\
\hline ECON. CRIT. & 5 & 1 & 3 & 3 & 2,59002 & 0,512669 \\
\hline SOCIOL. CRIT. & 0,333 & 0,333 & 1 & 3 & 0,759836 & 0,150402 \\
\hline ORGAN. CRIT. & 0,2 & 0,333 & 0,333 & 1 & 0,386097 & 0,076424 \\
\hline
\end{tabular}

Table 2 Interdependence of the importance of rating criteria

According to the expression (2) and Table 2.

$$
\left[\begin{array}{cccc}
1 & 0,2 & 3 & 5 \\
5 & 1 & 3 & 3 \\
0,333 & 0,333 & 1 & 3 \\
0,2 & 0,333 & 0,333 & 1
\end{array}\right]
$$

Below determining the consistency of the matrix by:

$$
\mathrm{w}_{\mathrm{i}, \mathrm{j}}=\mathrm{w}_{\mathrm{j}, \mathrm{i}}{ }^{-1}
$$

Priority indicates how each characteristic affects our decision. Priority (p) is the ratio of matrix row's geometric mean and the sum of the geometric mean of all the lines:

$$
p_{i}=\frac{m_{i}}{\sum_{j=1}^{q} m_{j}}, q-\text { number of columns }
$$

Geometric mean for example the first line is calculated by:

$$
m_{1}=\sqrt[q]{\prod_{i=1}^{q} w_{1, i}}, \mathrm{q}=\text { number of columns }
$$


Then compare the alternatives and repeating the process for each of the criteria of the first level as the following tables.

\begin{tabular}{|c|c|c|c|c|c|c|}
\hline & DISPOSAL & $\begin{array}{c}\text { THERMAL. } \\
\text { TREAT. }\end{array}$ & COMPOSTING & AGRICULTURE & $\begin{array}{c}\text { GEOMETRIC } \\
\text { MEAN }\end{array}$ & PRIORITY \\
\hline DISPOSAL & 1 & 0,111 & 0,143 & 0,333 & 0,269702 & 0,045148 \\
\hline THERMAL TREAT. & 9 & 1 & 3 & 5 & 3,408658 & 0,570613 \\
\hline COMPOSTING & 7 & 0,333 & 1 & 3 & 1,626577 & 0,272291 \\
\hline AGRICULTURE & 3 & 0,2 & 0,333 & 1 & 0,66874 & 0,111948 \\
\hline
\end{tabular}

Table 3 Alternative weight ratios for environmental criterion

\begin{tabular}{|c|c|c|c|c|c|c|}
\hline & DISPOSAL & $\begin{array}{c}\text { THERMAL. } \\
\text { TREAT. }\end{array}$ & COMPOSTING & AGRICULTURE & $\begin{array}{c}\text { GEOMETRIC } \\
\text { MEAN }\end{array}$ & PRIORITY \\
\hline DISPOSAL & 1 & 0,142857 & 5 & 5 & 1,374708 & 0,237679 \\
\hline THERMAL TREAT. & 7 & 1 & 3 & 7 & 3,482005 & 0,602018 \\
\hline COMPOSTING & 0,2 & 0,333333 & 1 & 0,333333 & 0,386097 & 0,066754 \\
\hline AGRICULTURE & 0,2 & 0,142857 & 3 & 1 & 0,541082 & 0,09355 \\
\hline
\end{tabular}

Table 4 Alternative weight ratios for economical criterion

\begin{tabular}{|c|c|c|c|c|c|c|}
\hline & DISPOSAL & $\begin{array}{c}\text { THERMAL. } \\
\text { TREAT. }\end{array}$ & COMPOSTING & AGRICULTURE & $\begin{array}{c}\text { GEOMETRIC } \\
\text { MEAN }\end{array}$ & PRIORITY \\
\hline DISPOSAL & 1 & 0,111111 & 0,142857 & 0,333333 & 0,269702 & 0,045948 \\
\hline THERMAL TREAT. & 9 & 1 & 5 & 3 & 3,408658 & 0,580715 \\
\hline COMPOSTING & 7 & 0,2 & 1 & 3 & 1,431569 & 0,243889 \\
\hline AGRICULTURE & 3 & 0,333333 & 0,333333 & 1 & 0,759836 & 0,129449 \\
\hline
\end{tabular}

Table 5 Alternative weight ratios for sociological criterion

\begin{tabular}{|c|c|c|c|c|c|c|}
\hline & DISPOSAL & $\begin{array}{c}\text { THERMAL. } \\
\text { TREAT. }\end{array}$ & COMPOSTING & AGRICULTURE & $\begin{array}{c}\text { GEOMETRIC } \\
\text { MEAN }\end{array}$ & PRIORITY \\
\hline DISPOSAL & 1 & 0,111111 & 0,2 & 5 & 0,57735 & 0,086522 \\
\hline THERMAL TREAT. & 9 & 1 & 5 & 9 & 4,486046 & 0,672284 \\
\hline COMPOSTING & 5 & 0,2 & 1 & 3 & 1,316074 & 0,197228 \\
\hline AGRICULTURE & 0,2 & 0,111111 & 0,333333 & 1 & 0,293371 & 0,043965 \\
\hline
\end{tabular}

Table 6 Alternative weight ratios for organisational criterion

Using the priorities alternatives vector determine the best alternative. Priorities alternatives vector is obtained by multiplying the matrix priorities alternatives according to the criteria with vector priorities criteria. Priorities are written to the matrix in the following way: 


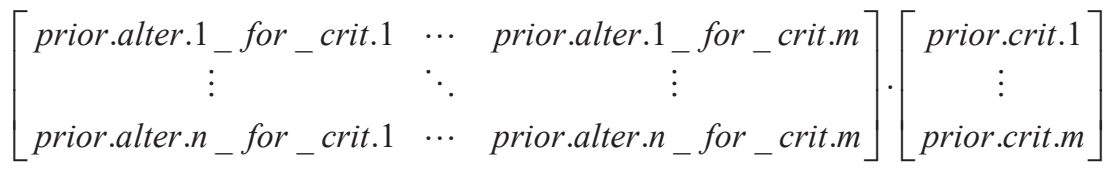

to rich alternatives rank shown in matrix:

$$
\left[\begin{array}{cccc}
0,045148 & 0,237679 & 0,045948 & 0,086522 \\
0,570613 & 0,602018 & 0,580715 & 0,672284 \\
0,272291 & 0,066754 & 0,243889 & 0,197228 \\
0,111948 & 0,09355 & 0,129449 & 0,043965
\end{array}\right] \cdot\left[\begin{array}{l}
0,260504 \\
0,512669 \\
0,159492 \\
0,076424
\end{array}\right]=\left[\begin{array}{l}
0,147135 \\
0,596003 \\
0,156910 \\
0,099952
\end{array}\right]
$$

The best alternative is thermal treatment (59.5003\%), the next one is composting $(15.6910 \%)$, then follow disposal (14.7135\%) and agriculture $(9.9952 \%)$

\section{Results and discussion}

The results show that the greatest influence on decision-making is economic criteria (0.512669). While stressing the importance of environmental criteria, it is second in importance $(0.260504)$ to the measure of nature and environmental protection respect to legislation prescribed value, and after then the greatest importance is the economic criteria.

In the last two places are sociological and organisational criteria that have similar values and priorities. Sociological criteria have priority of 0.159492 and organisational of 0.076424 .

Evaluating alternatives according to the environmental criteria, the highest priority as thermal treatment $(0.570613)$, as it has the greatest monitoring of air emissions (continuous measurements), and followed by composting (0.272291) and agricultural (0.111948). As expected, the above-mentioned reasons, the weakest priority has to be disposal (0.045148).

According to economic criteria, the highest priority has to be the same thermal treatment (0.602018), since it is the only alternative generating return of investment, producing energy of sewage sludge combustion. Next priority belongs to disposal because of low costs (0.237679), agriculture (0.09355) and composting (0.066754).

Priorities alternative to sociological criteria are ranked as for the environmental criteria: thermal treatment (0.580715), composting (0.243889), agricultural (0.129449) and disposal (0.045948). This is expected because the local community, which represents the most important criteria for the protection of nature and the environment. Of course, a significant impact on this criteria is the economic criteria which include cheaper energy for the local community and employment.

Priorities alternative to the organisational criteria are ranked: thermal treatment (0.672284), composting (0.197228), disposal (0.086522) and agricultural (0.043965). Since the thermal treatment sensitive process of organisational work organization is the most complex, but there is no improvisation (as opposed to disposal). The lowest ranked is agricultural since the location of work changes as needed. 
Using the priorities alternatives vector determine the best alternatives is the thermal treatment $(0.596003)$. On the second place there is composting $(0.156910)$, and the last are disposal (0.147135) and agriculture (0.099952).

\section{Conclusion}

With the implementation of Urban Wastewater treatment Directive 91/271/EEC [12] and Directive 1999/31/EC on the landfill of waste [11], Northern Croatia was faced with the rapidly increasing amount of sewage sludge. Therefore, it is necessary to find the most appropriate way to handle it, while considering geographical, cultural, economic, social and financial features of the County.

By 2023, in Northern Croatia, the agglomerations for collecting the sewage and water treatment systems are going to be constructed. All the devices will be based on the mechanical-biological method of purification [3]. However, the work of water treatment system produces a problem of sludge management. The practical and technical challenges of sludge handling are: stabilisation, reducing the water content and sludge volume to the minimum, utilising the energy potential when economically possible, reducing the number of harmful micro-organisms if people, animals or plants are in contact with the sludge, as well as recovering phosphorus for agriculture.

The hierarchical model of the decision making problem by defining the goal, criteria and alternative solutions is developed. On each level of the hierarchical model the elements of the model are compared with one another in pairs, and the preferences are expressed by using the Saaty's scale. Moreover, APH model compares the alternative pairs (thermal processing, deposition on agricultural land, disposal to waste repositories and composting) among each other. The intensities and weight preferences of one alternative over another are selected within the required criteria (economic, ecological, organisational and sociological).

Based on the results of modelling with AHP method in order, to choose the most acceptable disposal of sewage sludge in the Northern Croatia as the most acceptable variant imposes thermal treatment. Other alternative solutions are as follows: use sewerage sludge on agricultural areas or compost it.

\section{References}

[1] Q. Cai, C. Mo, Q. Wu, Q. Zeng, A. Katsoyiannis, "Concentration and speciation of heavy metals in six different sewage sludge-compost", Journal of Hazardous Materials, vol. 147, p.p. 1063-1072, 2007.

[2] M. Climent, I. Ferrer, M. Baeza, A. Artola, F. Vazquez, X. Font, "Effects of thermal and mechanical pretreatments of secondary sludge on biogas production under thermophilic conditions", Chemical Engineering Journal, vol. 133, p.p. 335-342, 2007.

[3] L. Gotal Dmitrović, V. Dušak, A. Anić Vučinić, “The Development of Conceptual, Mathematical and System Dynamics Model for Food Industry Wastewater Purifying System", JIOS, vol. 39, no 2, 2015. 
[4] V. Hasanbašić, A. Anić Vučinić, "Sewage sludge production and handling in Croatia and the European Union" in Environmental Management; Trends and Results, Faculty of Chemical Engineering and Technology, University of Zagreb, Zagreb, 2007, pp. 105-112.

[5] M. Hetherington, M. Moore, R. Pepperman, T. G. Shea, L. Stone, R. Reirners, P. Rom, (2006). "Emerging Technologies for Biosolids Management”. [Online]. Available: http://nepis.epa.gov/Exe/ZyPURL.cgi?Dockey=P1006DGM.txt

[6] Hrvatske vode. (2014). "Višegodišnji program gradnje komunalnih vodnih građevina 2014-2023”. [Online]. Available:

http://www.mps.hr/UserDocsImages/SAVJETOVANJA\%20ZI/2015/Viseg odisnji\%20program\%20gradnje\%20KVG_listopad_2014.pdf

[7] M. Išlić, (2012) “Analitička metoda hijerarhijskog odlučivanja u planiranju distribucijskih mreža” Završni rad, FER, Sveučilište u Zagrebu. [Online]. Available:

http://ferko.fer.hr/ferko/EPortfolio!dlFile.action;jsessionid=C284BD3931D DBF708DC87DC96E58BA95? id=310

[8] T. L. Saaty, "Relative Measurement and its Generalization in Decision Making: Why Pairwise Comparisons are Central in Mathematics for the Measurement of Intangible Factors - The Analytic Hierarchy/Network Process". RACSAM Rev. Acad. Cien. Serie A. Mat, vol. 102, no. 2, pp. 251 318, 2008. [Online]. Available: http://www.rac.es/ficheros/doc/00576.PDF

[9] T. L. Saaty, K. Peniwati, Group Decision Making: Drawing out and Reconciling Differences. Pittsburgh, Pennsylvania: RWS Publications, 2008. [Online]. Available:

http://bookereads.com/pdf1/free.php?asin=B00GP3N5RQ

[10] P. Sikavica, T. Hunjak, N. Begičević Ređep, T. Hernaus, Poslovno odlučivanje, Školska knjiga, Zagreb, 2014.

[11] Council Directive 1999/31/EC of 26 April 1999 on the landfill of waste. [Online]. Available:

http://www.central2013.eu/fileadmin/user_upload/Downloads/Document Centre/OP_Resources/Landfill_Directive_1999_31_EC.pdf

[12] Council Directive 91/271/EEC of 21 May 1991 concerning urban waste water treatment. [Online]. Available: http://eur-lex.europa.eu/legalcontent/HR/TXT/PDF/?uri=CELEX:31991L0271\&from=EN 